\title{
Kerry Alcorn Border Crossings: U.S. Culture and Education in Saskatchewan, 1905-1937
}

Montreal and Kingston: McGill-Queen's University Press, 2013. 232 pp.

\section{Anthony Di Mascio}

Bishop's University

Histories of education in Canada characteristically represent the development of education in the west as an extension of patterns and policies emanating from Ontario. In Border Crossings: U.S. Culture and Education in Saskatchewan, 1905-1937, Kerry Alcorn challenges us to think about Saskatchewan's educational development, and its political history, in an entirely different way. American culture and education policy, he contends, penetrated Saskatchewan between 1905 and 1937. As such, Saskatchewan's political culture and public policy can be seen to be more closely akin to American forms than we have previously supposed, particularly as they took shape in the Midwest and plains states. Inspired by his own cross-border travels between Saskatchewan and Kentucky while undertaking graduate studies in Lexington, Alcorn sets out not to rewrite history, but rather to provide an alternative way to think about the history of education in Saskatchewan. In the end he succeeds, and, indeed, opens new avenues of exploration into understanding the shape and form of educational developments across the continent.

The book is divided into two parts; the first part contains three chapters which consider how American culture was transferred to Saskatchewan. The work of George S. Tomkins on the history of the Canadian curriculum clearly influences the author, but at the same time Alcorn admits that he cannot reconcile Tomkins's understanding of culture in Canada with his own experiences traversing the Saskatchewan and midwestern US borderland region. For Tomkins, the history of education in Canada reflects the values of an Anglo-Celtic majority which, Alcorn writes, "pays homage to Protestant and British cultural norms while resisting American hegemony" (7). According to Alcorn, however, the Anglo-Celtic majority, so central to Tomkins's arguments at a national level, never really existed in Saskatchewan, especially between 
1905 and 1937. Nor did the people of Saskatchewan resist American hegemony. Instead, Alcorn suggests, they embraced it. Alcorn finds that the type and quality of anti-Americanism that repelled republican influences in the East, particularly after the War of 1812, never took hold in Saskatchewan. In fact, many of the immigrants who came to Saskatchewan, especially after 1905 when free land on the American frontier had disappeared, brought with them various aspects of American culture, which would help forge an emerging Saskatchewan identity. Alcorn identifies three crucial constructs of American culture that ultimately influenced Saskatchewan educational policymaking: conceptions of democratic government (schools themselves being intensely democratic); rejection of the eastern corporate power; and the concept of the West, including the land itself. "American culture was so warmly received in Saskatchewan largely because the Canadian west and the American west were part of the same environment - an environment that changed when one crossed west of the ninety-eighth meridian, but not when one crossed the forty-ninth parallel" (60).

The second part of Border Crossings looks specifically at the making of Saskatchewan's education system. Understanding the history of that system, the author posits, requires that we understand its predominantly rural nature. With a burgeoning heterogeneous population in a "harsh, remote, and unforgiving 'last best west"” (65), Alcorn suggests that Saskatchewan's policymakers looked in the only direction that offered relevant experience and guidance: south. It was there that they found educational thinkers and policymakers who had already struggled with the problems of a growing western frontier, and so had ready-made solutions to school reforms on the prairies that eastern Canada simply could not provide. Alcorn identifies five ways in which US culture influenced Saskatchewan education: the hiring of US-trained teachers; dependence on American books in teachers' colleges; the pursuit of graduate studies in education in the United States by Saskatchewan educational leaders; educational tours of the United States by provincial policymakers; and, finally, the use of American textbooks in Saskatchewan schools. In isolation each of these American influences seems modest. In concert, however, their impact becomes profound.

An interesting aspect of this book is its close analysis of a largely overlooked school reformer in Canadian educational history. Harold Waldstein Foght was an American brought on loan from the Bureau of Education in Washington, D.C. to examine and report on Saskatchewan schools during 1916 and 1917. The hope was that he could help Saskatchewan modernize its school system. Many of the problems Foght identified were not new to Saskatchewan's policymakers: the need for rural school consolidation; the necessity to replace a traditional curriculum with one more suited to the practical demands of a predominantly agricultural society; and the challenge to reform the school system's administrative superstructure. Although policymakers recognized the problems, the Saskatchewan government still needed the influence of an outside authority, Alcorn contends, to legitimate their efforts. Yet, Alcorn also admits that, at the level of the people, so deeply populist in their thinking, the threat of losing local control over their educational future prevented the adoption of many of Foght's recommended reforms until the 1940s or later. 
Another strength of this book is the in-depth attention given to the foundational years of the University of Saskatchewan, and what the author calls its "culture of emulation" (119). Alcorn argues that higher education in Saskatchewan was modelled not on the liberal universities of eastern Canada but on the more practical universities of the US Midwest, which emphasized service and vocational training - particularly in applied science and engineering, but also in agricultural and mechanical instruction. Immediately upon his appointment as president of the University of Saskatchewan, Walter Murray embarked on a sociological tour of midwestern American Universities, whose challenges, he felt, were similar to those of Saskatchewan's higher education institutions. Despite the numerous, well-established universities in Canada's East, from which he himself emerged, Murray instead looked south, Alcorn concludes, for his inspiration. The author ends his study by grappling with the meaning of American educational emulation in Saskatchewan. The rejection of eastern models of schooling was a persistent theme throughout the first four decades of the twentieth century, which, as in the United States, helped forge a distinct western identity. Educational policymakers in Saskatchewan purposefully turned their perspective south where they appropriated the symbols of the US West in order to shape the Canadian West.

Despite a gripping analysis, there are some inconsistencies in Alcorn's thinking that are difficult to ignore. For example, he never fully reconciles how it is that Saskatchewanians looked south for models of reform, and even enlisted an American to report upon and recommend changes to Saskatchewan's system of schooling, but then rejected the American solutions that were offered, such as rural school consolidation. Moreover, despite contending that Saskatchewanians resisted eastern Canadian educational ideas, Alcorn readily admits that the framers of the University Act in 1907 modelled Saskatchewan's new university on Ontario's Report of the Royal Commission on the University of Toronto in 1906. Finally, Alcorn's logic is muddied when he points out that in his quest for an agricultural college, Murray failed in his push for a new campus in Regina, but then supposes that Murray was shrewd in "keeping his [the University of Saskatchewan in Saskatoon] as the only campus in the province" (140).

Despite these minor objections, this book succeeds in raising a world of new questions about the history of education in Saskatchewan, the West, and all of Canada. While Alcorn did not set out to rewrite the history of Saskatchewan or Canadian education, he has certainly met his objective of providing an alternative way to think about them. Canadians take pride in explaining how and why they differ from Americans. Between 1905 and 1937 on the Canadian Prairies, however, Alcorn finds people who did not worry much about such differences. To them, there were few differences, in fact, that separated their lives from those of their American kith and kin. Geographically and culturally, the Canadian West and the American West were intimately entwined. Alcorn has done a remarkable job in highlighting the similarities and how they shaped the history of education in Saskatchewan. Border Crossings will challenge historians of education across the continent to think differently about educational developments in North America and to make greater sense of our schools' shared histories. 